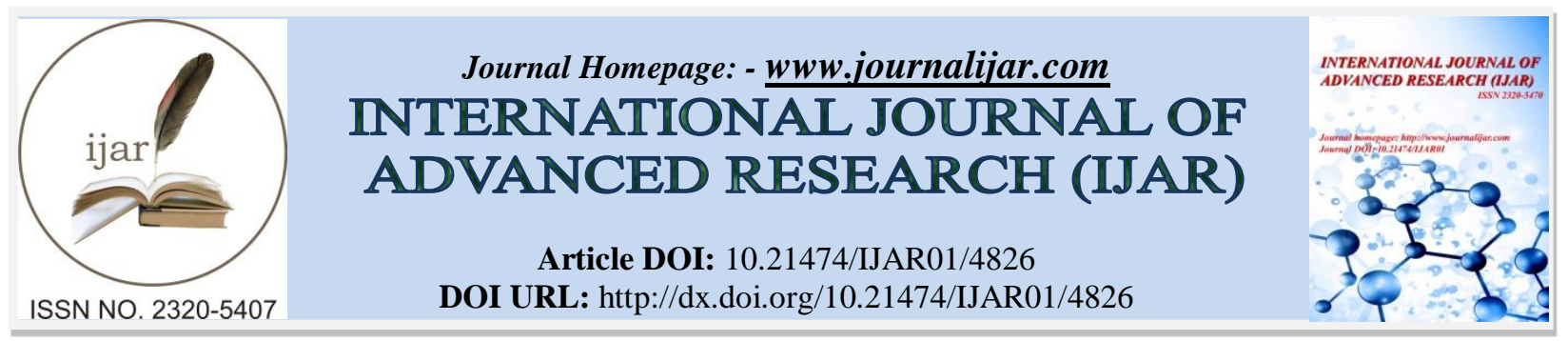

RESEARCH ARTICLE

\title{
SYNTHESIS, SPECTROSCOPIC, ANTICANCER, ANTIMICROBIAL AND ANTIOXIDANT STUDIES OF HOMO-BINUCLEAR Cu(II), Co(II), Ni(II) AND Mn(II) COMPLEXES WITH POLYDENTATE SCHIFF BASE LIGAND.
}

Jayalakshmi Rajendran, Anbarasu Govindharaji, Chozhanathmisra Manickam and *Rajavel Rangappan. Department of Chemistry, Periyar University, Salem-636 011, Tamilnadu, India.

\section{Manuscript Info}

........................

\section{Manuscript History}

Received: 12 May 2017

Final Accepted: 14 June 2017

Published: July 2017

Key words:-

Schiff base, TGA/DTA, P-XRD,

Anticancer, Antioxidant.

\section{Abstract}

A series of homo-binuclear $\mathrm{Cu}(\mathrm{II}), \mathrm{Co}(\mathrm{II}), \mathrm{Ni}(\mathrm{II})$ and $\mathrm{Mn}(\mathrm{II})$ metal complexes of Schiff base which was derived from 2,6diaminopyridine and glyoxal have been synthesized. The plausible geometry of Schiff base and its binucleating metal complexes were examined by means of elemental and thermal analysis, molar conductance, ${ }^{1} \mathrm{HNMR}, \mathrm{UV}-\mathrm{Vis}$, IR, ESR and mass spectra. From the spectral studies, a six coordinate environment around the metal dimers was confirmed. Both of the Schiff base and its metal complexes were tested for their in vitro antimicrobial activities against some bacterial and fungal strains. Schiff base and its metal complexes were also investigated for its cytotoxic effect against human breast cancer (MCF7) cell lines and it was observed that homo-binuclear $\mathrm{Cu}$ (II) and Co(II) complexes showed a good antitumor activity. The antioxidant activity was measured by DPPH method and the result showed that few metal complexes have been more potential activity.

Copy Right, IJAR, 2017,. All rights reserved.

\section{Introduction:-}

Nitrogen and oxygen containing privileged Schiff bases and their metal complexes played a vital role in the progress of coordination chemistry ensuing in a substantial number of publications, ranging from pure synthetic work to physicochemical [1] and biochemically significant studies of metal complexes [2-3] and also establish wide range of applications. Polydentate Schiff bases have been generally used as ligands, since they can be simply attached to metal ions due to the formation of highly stable coordination compounds. These Schiff base complexes show a huge variety of catalytic, [4] biological, [5] antifungal,[6] antitumor and anti HIV activities[7]. Recently, abundant research on macrocyclic complexes have been focused on species containing the first-row transition metal Schiff base [8]. Furthermore, pyridine based Schiff bases were a significant class of bioactive compounds in medicinal and pharmaceutical fields $[9,10]$. The above results encouraged making the present study that deals with the synthesis and characterization of heterocyclic homo-binuclear Schiff base complexes derived from 2,6-diaminopyridine and glyoxal containing a NO donor system with some divalent metal ions, namely $\mathrm{Cu}(\mathrm{II}), \mathrm{Co}(\mathrm{II}), \mathrm{Ni}(\mathrm{II})$ and $\mathrm{Mn}$ (II) along with their better biological activity due to their potentially useful properties. 


\section{Experimental Methods:- \\ Reagents and chemicals:-}

The chemicals such as 2, 6-diaminopyridine and glyoxal were getting from Sigma Aldrich and used without further purification. The metal salts were obtained from Merck with analytical grade. All other reagents and solvents were purchased from commercial sources of analytical grade and used as received.

\section{Physical Measurements:-}

The melting/decomposition points were resolute by employing a finely powdered sample in a glass capillary and heating by using Technico Melting point apparatus. The FT-IR spectra were recorded using JASCO/FT-IR 410 on $\mathrm{KBr}$ spectrometer discs in the range of $4000-400 \mathrm{~cm}^{-1}$. UV-Vis spectral studies were conducted on a Perkin Elmer Lambda-25 UV-Vis. spectrophotometer using DMSO as a solvent in the range of 200-800 $\mathrm{nm}$. The molar conductivity measurements of the metal complexes were accomplished in $\sim 10^{-3} \mathrm{M}$ DMSO solutions working a Digital/TDS conductivity meter (MK509). The ${ }^{1} \mathrm{H}$ NMR was recorded using a bruker spectrometer employing DMSO as a solvent. The mass spectral study was recorded using JEOL GC Mate II(EI) mass spectrometer. The spectrum of ESR was performed on a JES-FA200 spectrometer functioning in the X-band with a frequency of 9.21 GHz. Powder X-ray diffraction analysis was performed using RIGAKUMINI FLEX II. TGA/DTA analysis was carried out on a PerkinElmer thermal analysis method.

\section{Synthesis of Schiff base ligand (L):-}

A hot ethanolic solution of 2,6-diaminopyridine $(0.4365 \mathrm{~g}, 4 \mathrm{mmol})$ was mixed with an ethanolic solution of glyoxal $(0.27 \mathrm{ml}, 6 \mathrm{mmol})$ was continuously heated for 3 hours in a water bath refluxed at $80^{\circ} \mathrm{C}$. The reaction mixture was changed from reddish brown to brown color precipitate. It was filtered off and washed with several times in ethanol and dried in air.

\section{Synthesis of homo-binuclear Schiff base metal complexes:-}

A general procedure has been employed for the synthesis of new metal complexes. A mixture of one mmol $(0.32031$ g) of Schiff base which was dissolved in $10 \mathrm{ml}$ of DMF and $10 \mathrm{ml}(2 \mathrm{mmol})$ of ehanolic hydrate metal salts of $\mathrm{Cu}(\mathrm{II}), \mathrm{Co}(\mathrm{II}), \mathrm{Ni}(\mathrm{II})$ and $\mathrm{Mn}(\mathrm{II})$ were heated at $80{ }^{\circ} \mathrm{C}$ under reflux. After $3 \mathrm{~h}$ refluxion, the color of the reaction mixture was changed and desired metal complexes were obtained in moderate yield. The formed homo-binuclear metal complexes were filtered off and washed with ethanol in many times and then dried in vacuo. 


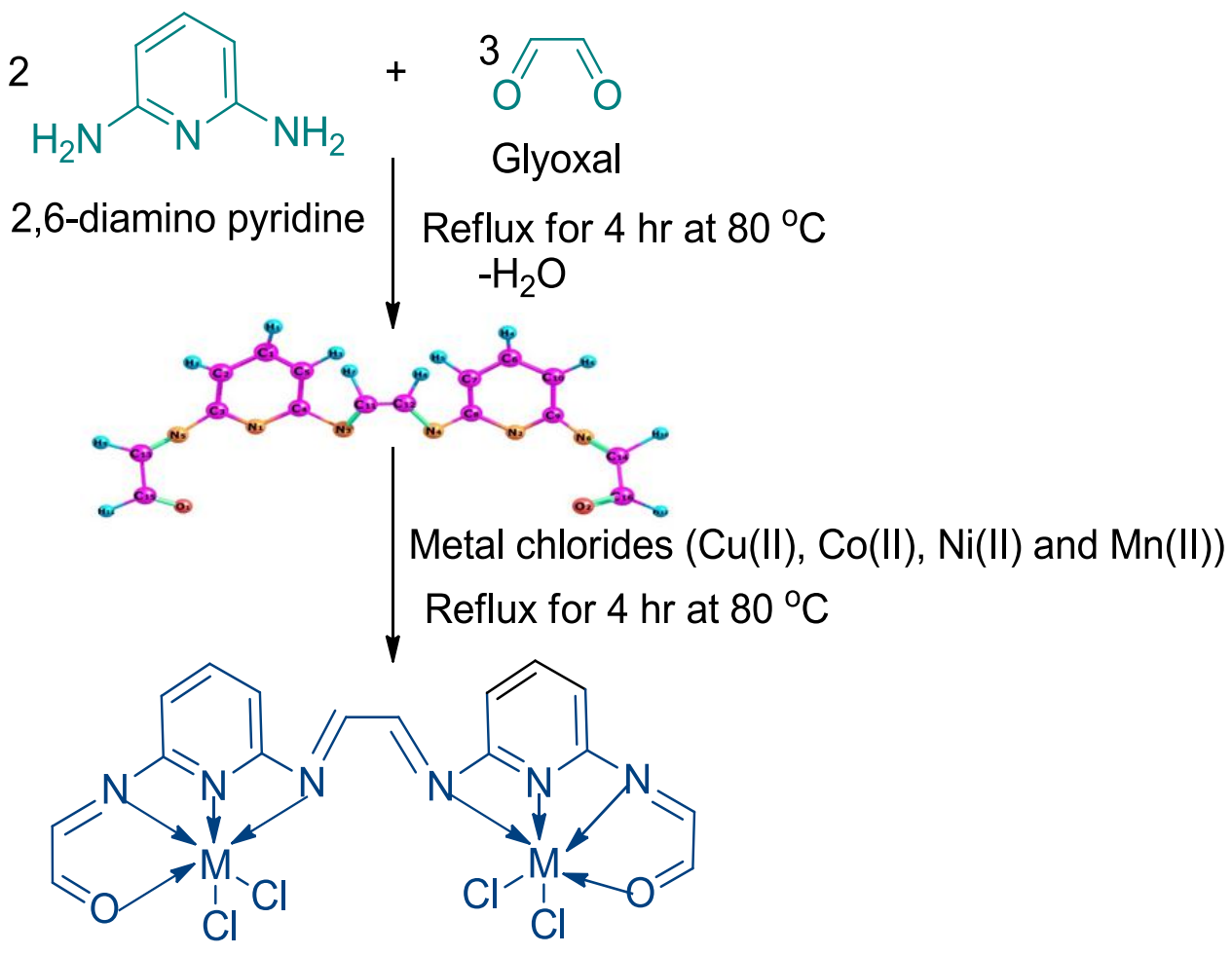

\section{Schiff base metal complexes}

Scheme 1:- Schematic route for synthesis of Schiff base and its homo-binuclear metal complexes

\section{Biological properties:-} Antibacterial Activity:-

The in vitro biological activity of Schiff base and their homo-binuclear metal complexes were tested against four bacterial strains such as Staphylococcus aureus and Bacillus subtilis as gram +ve bacteria while Escherichia coli and Salmonella typhi as gram -ve bacteria. The screening effect was carried out using a disk diffusion technique, in the presence of agar nutrient as the medium. The test solution was filled in the well (6 mm diameter) and the plates were inoculated at $37{ }^{\circ} \mathrm{C}$ for $48 \mathrm{~h}$. During this time, the growth of the inoculated microorganisms was affected and then the developed inhibition zones on the plates were measured. The antibacterial activity of each compound was associated with that of standard antibiotics (Ciprofloxacin). DMSO was used as a control under the same conditions for each organism and no activity was found. The activity results were calculated as a mean of triplicates.

\section{Antifungal Activity:-}

The synthesized compounds were tested against Aspergillus fumigatus and Aspergillus flavus by cup-plate method. The disc have $5 \mathrm{~mm}$ diameter and $1 \mathrm{~mm}$ thickness was filled with the test solution using a micropipette and the plates were incubated at $37^{\circ} \mathrm{C}$ for $72 \mathrm{~h}$. During this time, the test solution was diffused and affected the growth of the inoculated fungi. After $36 \mathrm{~h}$ of incubation at $37^{\circ} \mathrm{C}$, the diameter of the inhibition was measured. Compounds showing hopeful antifungal activity were selected for minimum inhibitory concentration studies. Minimum inhibitory concentration (MIC) was the lowermost concentration of an antifungal compound, inhibiting the visible growth of microorganisms after overnight incubation. MIC was important in diagnostic laboratories to approve resistance of microorganisms to antimicrobial agents and also to screen the activity of new antimicrobial agents.

\section{Cell lines and Culturing:-}

The anticancer activities of the synthesized Schiff base and their metal complexes were carried out using MCF7 cell line (human breast cancer cells) by applying the MTT colorimetric assay. This method was based on reduction of the yellow colored water soluble tetrazolium dye to purple coloured insoluble formazan crystals. The cell culture medium was steadily washed with PBS (Phosphate-buffered saline) solution and $10 \mu \mathrm{L}$ of MTT reagent were added 
in the wells then incubated at $37{ }^{\circ} \mathrm{C}$ for approximately $2-5 \mathrm{~min}$. The monolayer cells were isolated with enough reagent of trysin-EDTA to make single cell suspension and the viable cells were checked using a Haemocytometer. The cells were diluted with a growth medium of 10\% FBS (Fetal Bovine serum), 2\% penicillin-Streptomycin solution, $50 \mu \mathrm{g} / \mathrm{ml}$ Gentamycin, and $0.25-2.5 \mu \mathrm{g} / \mathrm{ml} \mathrm{Amphobotericin.} \mathrm{After} \mathrm{that} \mathrm{the} \mathrm{cells} \mathrm{were} \mathrm{then} \mathrm{resuspended} \mathrm{in}$ the freezing medium having 40\% FBS and 5\% DMSO and were placed on wet ice for $24 \mathrm{~h}$. A concentration of 100$200 \mu \mathrm{g} / \mathrm{ml}$ of a cell suspension in a culture medium at a required cell density $(25,000-50,000$ cells per well) were seeded into 96-well plates and incubated for $24 \mathrm{~h}$. After $24 \mathrm{~h}$, appropriate concentrations $(3.125-250 \mu \mathrm{g} / \mathrm{ml})$ of the test agents were added to the cells and incubated at $37{ }^{\circ} \mathrm{C}$ in a $5 \% \mathrm{CO}_{2}$ atmosphere. At the end of the incubation period, the plates were removed from the incubator and added $1 \%$ of MTT in PBS. The MTT containing medium was then rejected and the cells were washed with PBS. The formed formazan crystals were dissolved by adding 100 $\mu \mathrm{L}$ of DMSO and this was assorted suitably by pipetting up and down. Spectrophotometrical absorbance of the formed purple blue formazan dye was measured in a spectrophotometer or an ELISA reader at $570 \mathrm{~nm}$. The medium without samples served as a control and a triplicate was maintained for all concentrations. From the absorbance, the \% inhibition was calculated. Spectrophotometrical absorbance of the purple blue formazan dye was measured in a micro-plate reader at $570 \mathrm{~nm}$.

$$
\% \text { Cell viability }=A_{C}-\frac{A_{t}}{A_{c}} \times 100
$$

Where $A_{c}$ is the mean absorbance of control and $A_{t}$ is the mean absorbance of test compound.

\section{Antioxidant Assay with DPPH Radical:-}

The free radical scavenging activities of the synthesized compounds have been done using DPPH radical (1,1diphenyl-2-picrylhydrazyl) inhibition assay [11]. It is one of the standard and rapid technique for screening the free radical scavenging activity of specific compounds. The experiment has been performed by maintaining the DPPH radical with various concentrations $(100,200,300,400$, and $500 \mu \mathrm{g} / \mathrm{mL})$ of the synthesized compounds in $1 \mathrm{~mL}$ DMF and were added to $1.0 \mathrm{~mL}$ of $0.4 \mathrm{mM}$ methanol solution of DPPH and were stirred thoroughly. The whole setup has been incubated around $30 \mathrm{~min}$ at room temperature, after $30 \mathrm{~min}$ periods the scavenging ability were determined $517 \mathrm{~nm}$. The calculated value of DPPH was compared with the absorbance of control (ascorbic acid (vitamin C)). Radical Scavenging activity was calculated using the following formula:

$$
\% \text { Scavenging of DPPH }=\left[\frac{\mathrm{ABS} \text { control }- \text { ABS sample }}{\mathrm{ABS} \text { control }}\right] * 100
$$

\section{Results and Discussion:- \\ Molar Conductivity:-}

Molar conductivity measurements are valuable in reviewing the existence of moving electrolytic species in the solutions of complexes. It was measured at $1 \times 10^{-3} \mathrm{M}$ of each complex in DMSO at room temperature $\left(24-30^{\circ} \mathrm{C}\right)$. The metal complexes exhibited low molar conductivity values in the range of $2.30-3.20 \mathrm{Scm}^{2} \mathrm{~mol}^{-1}$ representing the non-electrolytic nature of the metal complexes, at which no free ions were present.

\section{IR Spectra:-}

The most valuable IR bands of the Schiff base ligand and their binuclear metal complexes were listed in Table 1 and shown in figs.1a and $1 \mathrm{~b}$. The IR spectrum of the ligand (HL) shows a $v(\mathrm{C}=\mathrm{N})$ peak at $1601 \mathrm{~cm}^{-1}$ indicative the formation of Schiff base. The IR spectra of all complexes show $v(C=N)$ bands in the region from $1564-1581 \mathrm{~cm}^{-1}$ and this phenomenon due to the coordinated of azomethine nitrogen to the metal ion [12]. The Schiff base ligand shows the band at 1442 and $766 \mathrm{~cm}^{-1}$, these bands were shifted in the region of $1405-1438 \mathrm{~cm}^{-1}$ and $776-788 \mathrm{~cm}^{-1}$ confirming the pyridine nitrogen atom also involving in the coordination sphere of the metal complexes [13,14]. The ligand exhibit a stretching vibration band of $v(\mathrm{C}=\mathrm{O})$ at $1726 \mathrm{~cm}^{-1}$. On complexation this band was shifted in the lower region of 1619-1652 $\mathrm{cm}^{-1}$, respectively [15]. Further indication for metal ions coordinated through the nitrogen, oxygen and chlorine atoms is the appearance of the new $v(\mathrm{M}-\mathrm{O}), \mathrm{v}(\mathrm{M}-\mathrm{N})$ and $v(\mathrm{M}-\mathrm{Cl})$ bands in the region of $612-636 \mathrm{~cm}^{-1}, 485-494 \mathrm{~cm}^{-1}$ and 331-386 cm${ }^{-1}$ correspondingly, these results were good agreement with earlier reports $[16,17]$. 
Table 1:- IR Spectrum of Schiff base and its metal complexes

\begin{tabular}{|c|c|c|c|c|c|c|c|}
\hline \multirow{2}{*}{ Compounds } & \multirow{2}{*}{$\begin{array}{c}v(C=N) \\
\left(\mathrm{cm}^{-1}\right)\end{array}$} & \multirow{2}{*}{$\begin{array}{c}v(C=O) \\
\left(\mathrm{cm}^{-1}\right)\end{array}$} & \multicolumn{2}{|c|}{$\begin{array}{l}\text { Pyridine ring } \\
\text { Deformations }\end{array}$} & \multirow{2}{*}{$\begin{array}{l}v(\mathrm{M}-\mathrm{O}) \\
\left(\mathrm{cm}^{-1}\right)\end{array}$} & \multirow{2}{*}{$\begin{array}{l}v(\mathrm{M}-\mathrm{N}) \\
\left(\mathrm{cm}^{-1}\right)\end{array}$} & \multirow{2}{*}{$\begin{array}{l}v(\mathrm{M}-\mathrm{Cl}) \\
\left(\mathrm{cm}^{-1}\right)\end{array}$} \\
\hline & & & In Plane & $\begin{array}{l}\text { Out of } \\
\text { plane }\end{array}$ & & & \\
\hline Ligand(L) & 1601 & 1726 & 1442 & 766 & - & - & - \\
\hline $\mathrm{Cu}_{2} \mathrm{LCl}_{4}$ & 1581 & 1628 & 1434 & 781 & 612 & 487 & 335 \\
\hline $\mathrm{Co}_{2} \mathrm{LCl}_{4}$ & 1578 & 1652 & 1438 & 776 & 614 & 494 & 364 \\
\hline $\mathrm{Ni}_{2} \mathrm{LCl}_{4}$ & 1564 & 1649 & 1405 & 783 & 636 & 489 & 386 \\
\hline $\mathrm{Mn}_{2} \mathrm{LCl}_{4}$ & 1576 & 1619 & 1406 & 788 & 623 & 485 & 331 \\
\hline
\end{tabular}

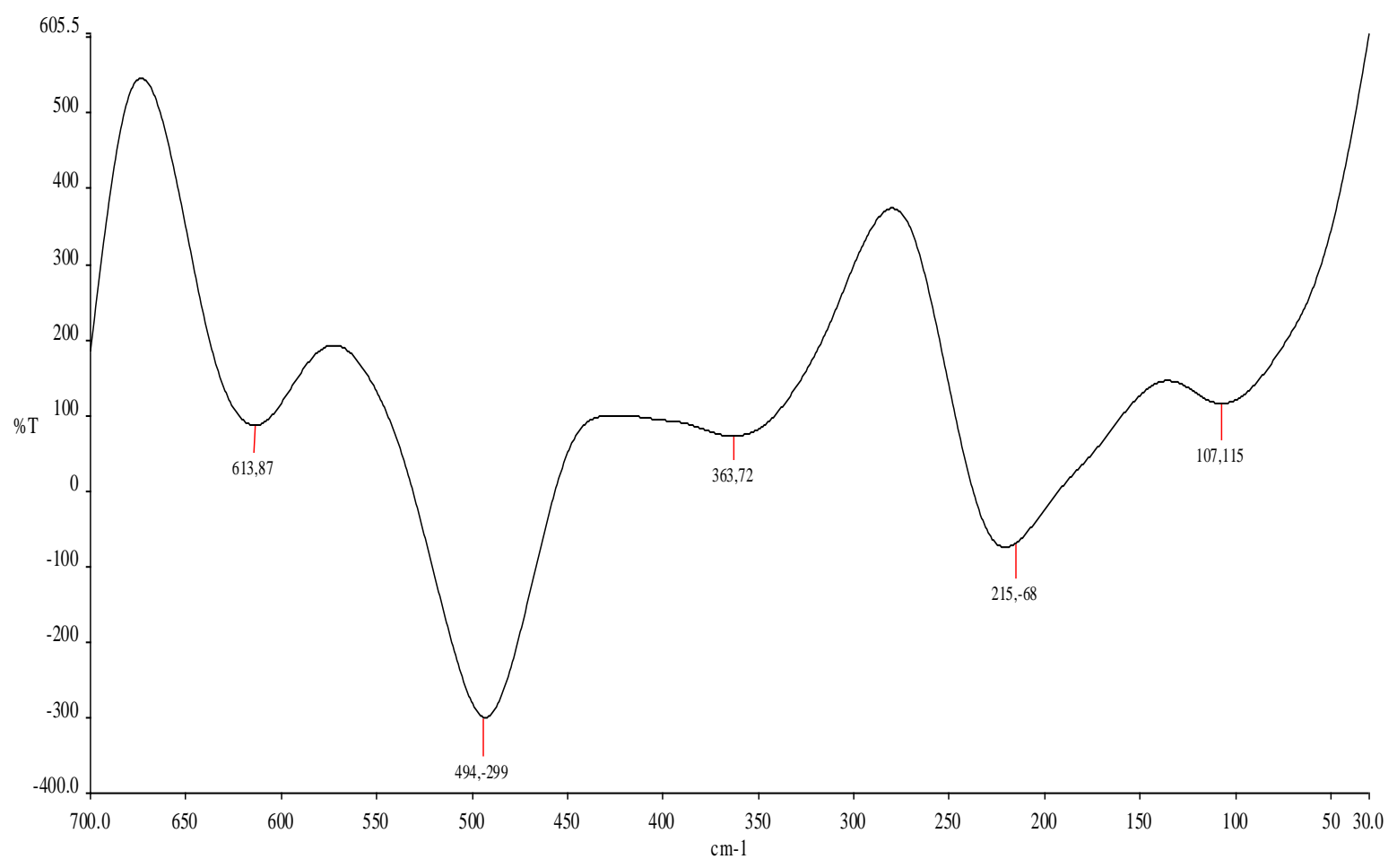

Fig. 1a:- IR Spectrum of homo-binuclear Co(II) complex 


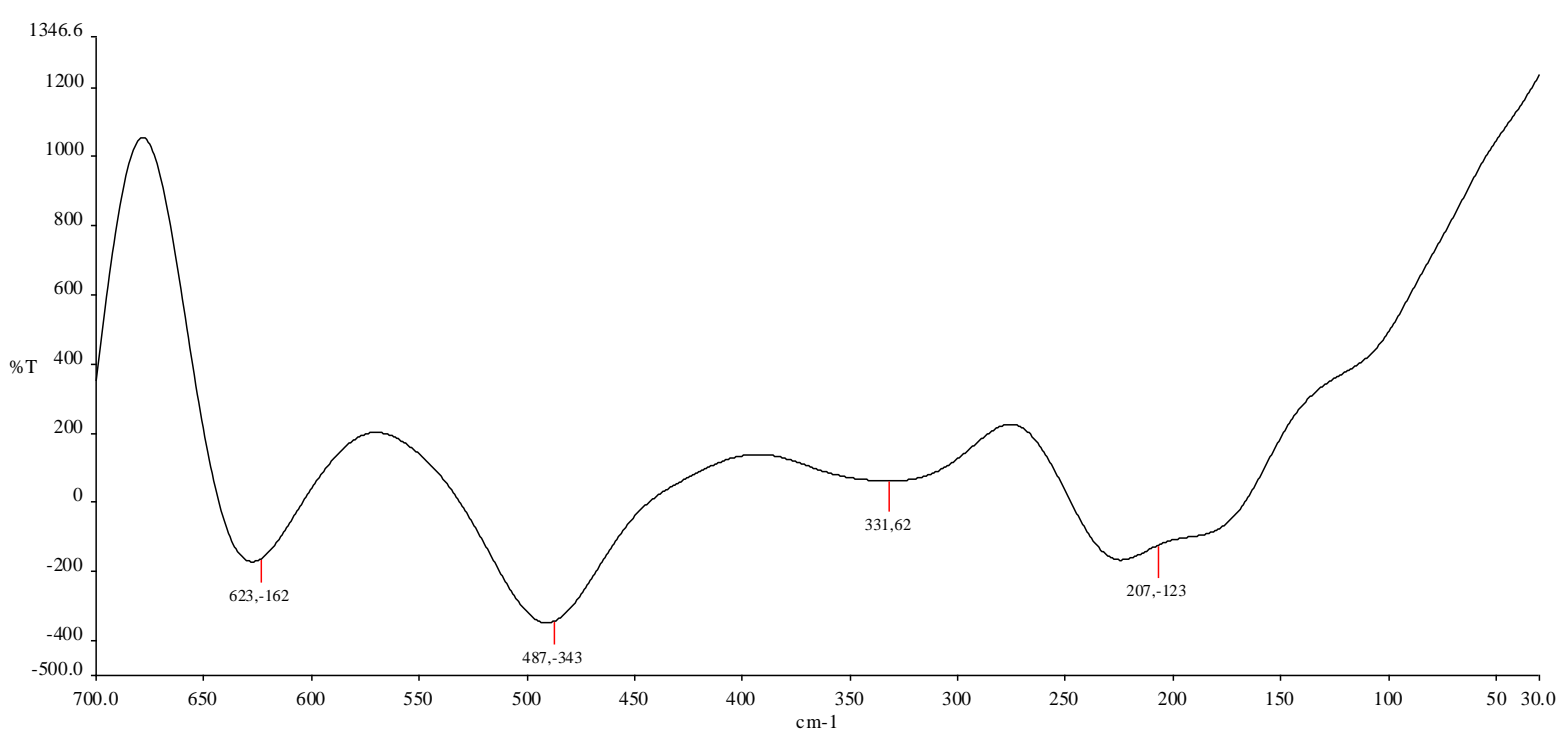

Fig. 1b:- IR Spectrum of homo-binuclear Mn(II) complex

\section{Electronic spectral studies:-}

The UV-Vis spectrum of the Schiff base and its homo-binuclear metal complexes were recorded in DMSO solution over the range of 200-800 $\mathrm{nm}$ and the spectral data were listed in Table 2. Schiff base ligand shows absorption bands at 303 and $372 \mathrm{~nm}$, illustrate the $\pi \rightarrow \pi^{*}$ transition and $n \rightarrow \pi^{*}$ transitions respectively. On complexation these bands were shifted in the region of 312-324 $\mathrm{nm}$ and $386-398 \mathrm{~nm}$. Electronic spectrum of the homo-binuclear $\mathrm{Cu}$ (II) complex exhibits the broad band covering the range of 690-712 $\mathrm{nm}$ corresponds to ${ }^{2} \mathrm{Eg} \rightarrow{ }^{2} \mathrm{~T}_{2} \mathrm{~g}$ transition and the magnetic moment value (1.78 B.M.) also favors the distorted octahedral geometry [18]. In the spectrum of homobinuclear Co(II) complex, the bands at 548 and $472 \mathrm{~nm}$ are related to the transitions ${ }^{4} \mathrm{~T}_{1} \mathrm{~g}(\mathrm{~F}) \rightarrow{ }^{4} \mathrm{~A}_{2} \mathrm{~g}(\mathrm{~F})$ and ${ }^{4} \mathrm{~T}_{1} \mathrm{~g} \rightarrow$ ${ }^{4} \mathrm{~T}_{1} \mathrm{~g}(\mathrm{P})$ respectively indicating the octahedral geometry and the magnetic moment of $4.7 \mathrm{~B} . \mathrm{M}$ value illustrated the complex was paramagnetic and three unpaired electrons consistent to a high spin of this geometry [19]. The spectrum of homo-binuclear Ni(II) complex exhibited two d-d bands at 612 and $442 \mathrm{~nm}$ corresponds to ${ }^{3} \mathrm{~A}_{2} \mathrm{~g}(\mathrm{~F})$ $\rightarrow{ }^{3} \mathrm{~T}_{1} \mathrm{~g}(\mathrm{~F})$ and ${ }^{3} \mathrm{~A}_{2} \mathrm{~g}(\mathrm{~F}) \rightarrow{ }^{3} \mathrm{~T}_{1} \mathrm{~g}(\mathrm{P})$ transitions, respectively, which describe the octahedral geometry of the Ni(II) complex [20]. This was further supported by the value of magnetic susceptibility (3.40 B.M). Electronic spectra of homo-binuclear $\mathrm{Mn}(\mathrm{II})$ complex exhibited weak absorption bands in the range 421 and $510 \mathrm{~nm}$ and these bands were assigned as ${ }^{6} \mathrm{~A}_{1} \mathrm{~g} \rightarrow{ }^{4} \mathrm{Eg}(4 \mathrm{D})$, and ${ }^{6} \mathrm{~A}_{1} \mathrm{~g} \rightarrow{ }^{4} \mathrm{~T}_{1} \mathrm{~g}(4 \mathrm{P})$ transitions, respectively, which is concordant with octahedral geometry of the metal complexes [21]. The observed magnetic moment value (6.13 BM) also supported high spin octahedral geometry for $\mathrm{Mn}(\mathrm{II})$ complex.

\section{Mass spectroscopy:-}

Mass spectrometry is one of the energetic methods for analysis of molecular weight and structure of the Schiff base ligand and its metal complexes. The mass spectrum of Schiff base ligand shown a molecular ion peak at $\mathrm{m} / \mathrm{z} 320$ confirms the proposed formulae (fig. 2a). The Schiff base also showed a series of peaks at 264, 209, 133 and 78 referred to the various fragments such as $\left[\mathrm{C}_{14} \mathrm{H}_{10} \mathrm{~N}_{5} \mathrm{O}\right]^{+},\left[\mathrm{C}_{12} \mathrm{H}_{9} \mathrm{~N}_{4}\right]^{+},\left[\mathrm{C}_{7} \mathrm{H}_{5} \mathrm{~N}_{2} \mathrm{O}\right]^{+}$and $\left[\mathrm{C}_{5} \mathrm{H}_{4} \mathrm{~N}\right]^{+}$, respectively. The intensity of these peaks contributes an indication of the stabilities of fragments and could be helped to decide molecular formula. The mass spectrum of the homo-binuclear $\mathrm{Cu}(\mathrm{II})$ complex displayed the parent molecular ions $[\mathrm{M}]^{+}$at $\mathrm{m} / \mathrm{z}=587$ corresponding to their molecular weight. The $\mathrm{m} / \mathrm{z}$ of the molecular ion peak confirms that the stoichiometry of the complex of $\left[\mathrm{M}_{2} \mathrm{LCl}_{4}\right]$ type. The peaks observed at $\mathrm{m} / \mathrm{z} 518,447$ and 383 assigned to $\left[\mathrm{Cu}_{2} \mathrm{LCl}_{2}\right]^{+}$ , $\left[\mathrm{Cu}_{2} \mathrm{~L}\right]^{+}$and $[\mathrm{CuL}]^{+}$, respectively. The being of the Schiff base ligand was showed by the peak at 320 (Calc.320.31). The results of elemental analyses and the mass spectrum of synthesized Schiff base and its homobinuclear $\mathrm{Cu}(\mathrm{II})$ complex were in reasonable agreement with each other's which confirm the proposed molecular formula (fig.2b). 


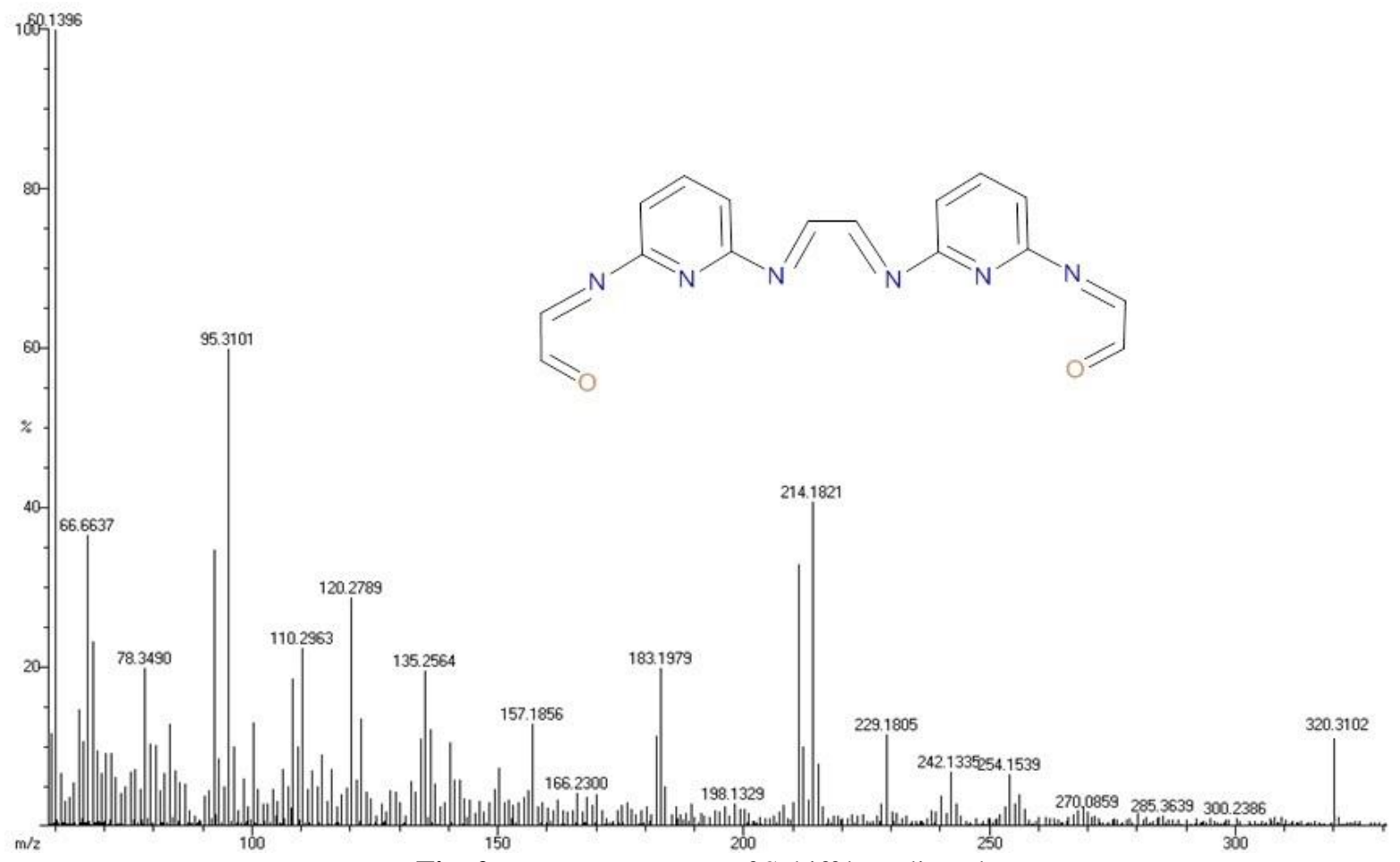

Fig. 2a:- Mass spectrum of Schiff base ligand.

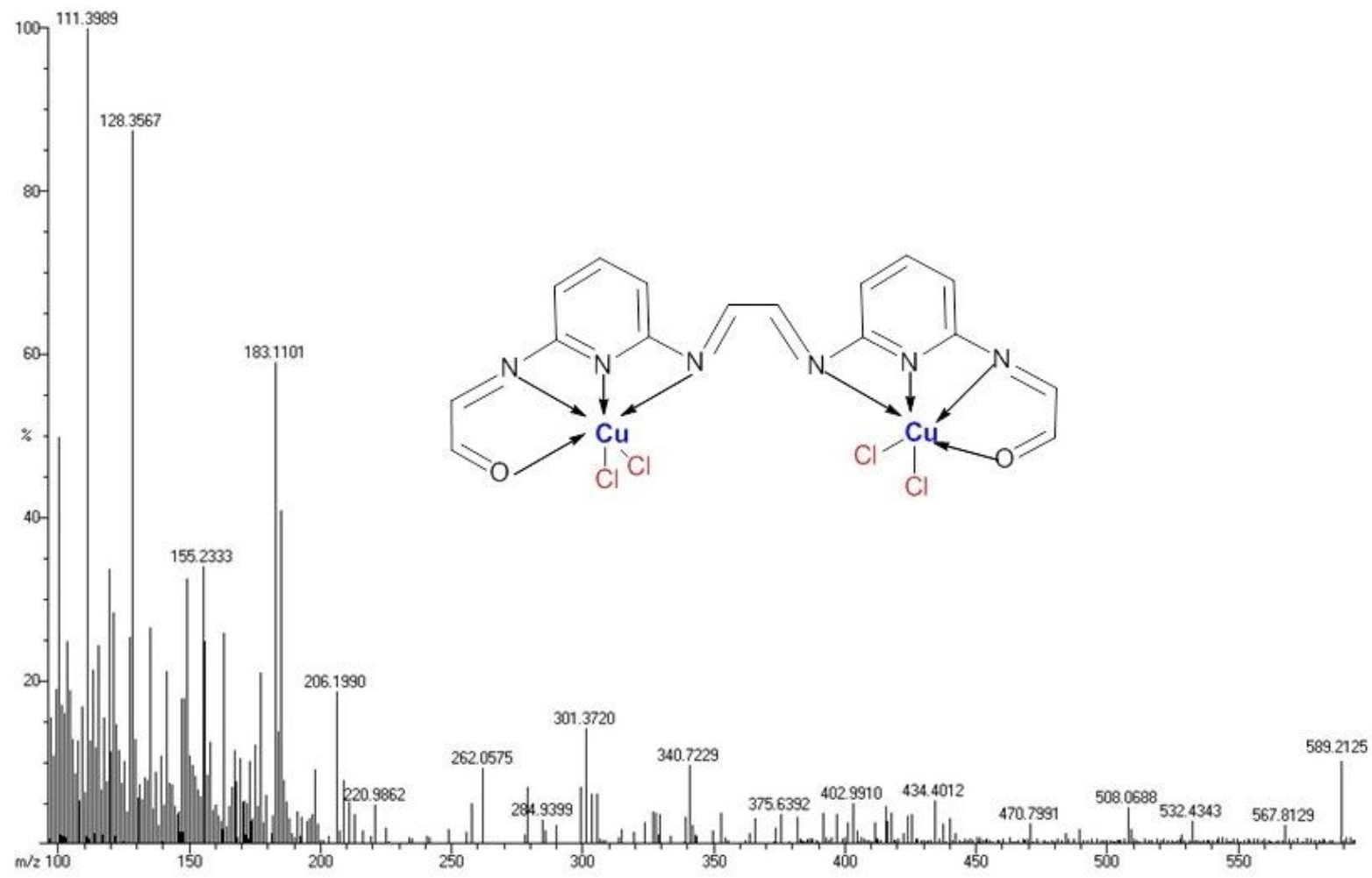

Fig. 2b:- Mass spectrum of homo-binuclear $\mathrm{Cu}(\mathrm{II})$ complex

Thermal Study:-

The thermal studies of homo-binuclear Schiff base metal complexes of $\mathrm{Cu}(\mathrm{II}), \mathrm{Co}(\mathrm{II}), \mathrm{Ni}(\mathrm{II})$ and $\mathrm{Mn}$ (II) were carried out using the thermogravimetric technique (TG) and differential thermogravimetric (DTG) in order to give 
more perception into the structure of the complexes [22]. Table 2 and fig. 3 gives the systematic thermal decomposition data for metal complexes. The TGA curves of homo-binuclear $\mathrm{Cu}$ (II) complex exposed that it decomposed in two thermal steps. The first decomposition peak occurred in the range $70-223{ }^{\circ} \mathrm{C}$ with a weight loss of $24.07 \%$ (23.81\% calc.). It was reliable with the elimination of $4 \mathrm{Cl}$. The second decomposition step arises in the range $223-698{ }^{\circ} \mathrm{C}$ with a weight loss of $54.36 \%$ (53.57\% calc.) might be ascribed to the loss of Schiff base ligand leaving two $\mathrm{Cu}$ metals as residue. The TG plot of $\mathrm{Co}_{2} \mathrm{LCl}_{4}$ displayed three decomposition steps. In first step the decomposition existed in the range $68-139{ }^{\circ} \mathrm{C}$ with a weight loss of $12.27 \%$ (12.05\% calc.) due to the loss of $2 \mathrm{Cl}$. The second step was occurred in the temperature range $139-304{ }^{\circ} \mathrm{C}$, with a net mass loss of $12.27 \%(12.53 \%$ calc.) which may be due to the elimination of $2 \mathrm{Cl}$. The third decomposition prevailed at the $304-684{ }^{\circ} \mathrm{C}$ range due to weight loss of $55.43 \%$ (55.46\% calc.) which corresponds to the elimination of ligand evacuate two Co metals as residue. The TG/DTG curves of $\mathrm{Ni}_{2} \mathrm{LCl}_{4}$ complex exhibited the first decomposition step in the range of $220-540{ }^{\circ} \mathrm{C}$. This was assigned to the removals of $4 \mathrm{Cl}$ with a weight loss of $24.48 \%$ (24.15\% calc.). The other decomposition step occurred in the range of $540-720{ }^{\circ} \mathrm{C}$ with a weight loss of $55.27 \%(55.20 \%$ calc.) which corresponds to the elimination of ligand leave two Ni metals as residue. Thermogram of homo-binuclear Mn(II) complex displayed two following decomposition steps. The first decomposition step occurs at the $93-540{ }^{\circ} \mathrm{C}$ range due to weight loss of $24.80 \%$ (24.56\% calc.) which corresponds to the elimination of $4 \mathrm{Cl}$. The second decomposition step occurred at $540-720{ }^{\circ} \mathrm{C}$ range, which assigned to the loss of $55.99 \%$ (55.26\% calc.) ligand. The metallic residue remained at the end of decomposition was assigned as two manganese metals.

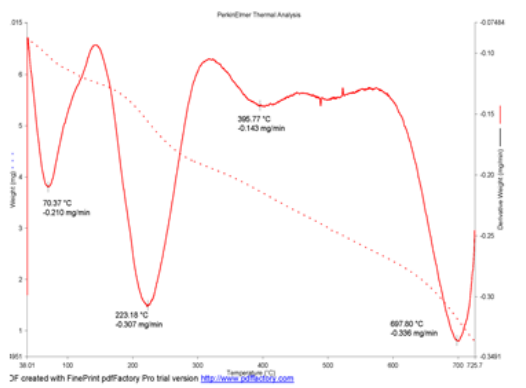

a

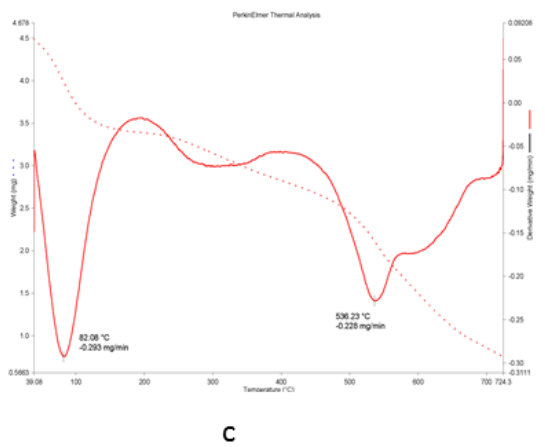

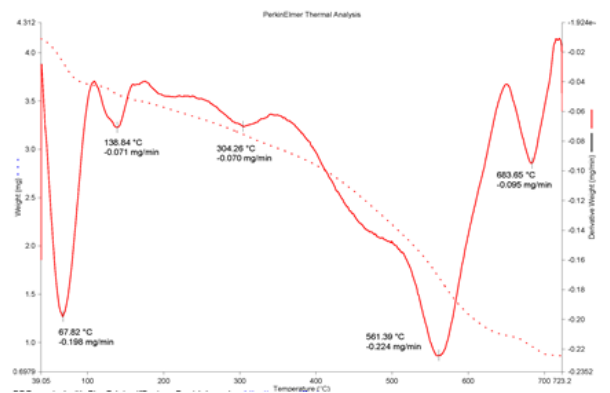

b

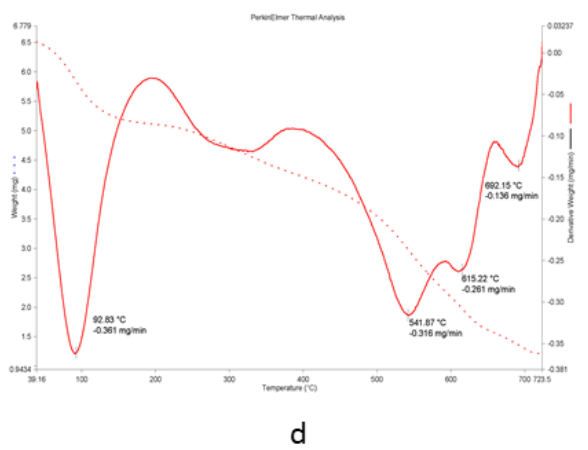

Fig. 3:- TGA/DTA curve for homo-binuclear metal complexes (a-Cu(II); b-Co(II); c- Ni(II); d- Mn(II) complex)

Table 2:- Thermogravimetric results of homo-binuclear Schiff base metal complexes

\begin{tabular}{|c|c|c|c|c|c|}
\hline \multirow[t]{2}{*}{ Complex } & \multirow{2}{*}{$\begin{array}{l}\text { Temperature } \\
\text { range } /{ }^{\circ} \mathrm{C}\end{array}$} & \multicolumn{2}{|c|}{ Mass loss (\%) } & \multirow[t]{2}{*}{ Loss moiety } & \multirow{2}{*}{$\begin{array}{l}\text { Peak assignment } \\
\text { due to loss moiety }\end{array}$} \\
\hline & & found & calc. & & \\
\hline \multirow[t]{2}{*}[\mathrm{Cu}_{2}\mathrm{LCl}_{4}]{} & $70-223$ & 24.07 & 23.81 & $4 \mathrm{Cl}$ & {$\left[\mathrm{Cu}_{2} \mathrm{~L}\right]$} \\
\hline & $223-698$ & 54.36 & 53.57 & $\mathrm{~L}$ & {$[2 \mathrm{Cu}]$} \\
\hline \multirow[t]{3}{*}[\mathrm{Co}_{2}\mathrm{LCl}_{4}]{} & $68-139$ & 12.27 & 12.05 & $2 \mathrm{Cl}$ & {$\left[\mathrm{Co}_{2} \mathrm{LCl}_{2}\right]$} \\
\hline & $139-304$ & 12.27 & 12.53 & $2 \mathrm{Cl}$ & {$\left[\mathrm{Co}_{2} \mathrm{~L}\right]$} \\
\hline & $304-684$ & 55.43 & 55.46 & $\mathrm{~L}$ & {$[2 \mathrm{Co}]$} \\
\hline \multirow[t]{2}{*}[\mathrm{Ni}_{2}\mathrm{LCl}_{4}]{} & $220-540$ & 24.48 & 24.15 & $4 \mathrm{Cl}$ & {$\left[\mathrm{Ni}_{2} \mathrm{~L}\right]$} \\
\hline & $540-720$ & 55.27 & 55.20 & $\mathrm{~L}$ & {$[2 \mathrm{Ni}]$} \\
\hline$\left[\mathrm{Mn}_{2} \mathrm{LCl}_{4}\right]$ & $93-540$ & 24.80 & 24.56 & $4 \mathrm{Cl}$ & {$\left[\mathrm{Mn}_{2} \mathrm{~L}\right]$} \\
\hline
\end{tabular}




\begin{tabular}{|l|l|l|l|l|l|}
\hline & $540-720$ & 55.99 & 55.26 & $\mathrm{~L}$ & {$[2 \mathrm{Mn}]$} \\
\hline
\end{tabular}

${ }^{1} \mathrm{H}$ NMR spectra of the Schiff base were recorded in d6-DMSO. The ${ }^{1} \mathrm{H}$ NMR spectra of the ligand demonstrated a multiple within the range 7.3-7.7 ppm which was assigned to aromatic protons. The azomethine protons $(-\mathrm{CH}=\mathrm{N}-)$ were appearing as a singlet at 7.83-8.14 ppm. The ligand showed a singlet peak at $9.7 \mathrm{ppm}$, belonging to the aldehydic protons.

\section{ESR spectra:-}

The X-band ESR spectra of homo-binuclear copper(II) complex were recorded at $9.21 \mathrm{GHz}$ frequency under a magnetic field strength of $3127 \mathrm{G}$ at room temperature and the figure were shown in fig. 4 . The $\mathrm{Cu}(\mathrm{II})$ complex shows the $\mathrm{g} \| 2.19, \mathrm{~g} \perp 2.03$ and gave 2.080 . The tendency $\mathrm{g} \|>\mathrm{g} \perp>2.002$ observed in $\mathrm{Cu}$ (II) complex under study shows that the unpaired electron is localized in the $\mathrm{dx} 2-\mathrm{y} 2$ orbital of the $\mathrm{Cu}(\mathrm{II})$ ion. The axial spectra, the g-values are related to exchange interaction coupling constant $(G)$ by the expression $G=(g \|-2) /(g \perp-2)$. The $G$ values reflect the spin interaction between $\mathrm{Cu}(\mathrm{II})$ centers of the binuclear $\mathrm{Cu}(\mathrm{II})$ complex. According to Hathaway and Billing [23], in our homo-binuclear $\mathrm{Cu}(\mathrm{II})$ complex, the $\mathrm{G}$ value comes out to be 6.33 which acclaims, the spin exchange interaction between the two copper ions were negligible. Thus, the values of EPR were in agreement with those obtained from the electronic spectra also support octahedral geometry for $\mathrm{Cu}(\mathrm{II})$ complex [24].

\section{X-Ray Diffraction:-}

The X-ray diffraction of the homo-binuclear metal complexes was scanned in the $2 \theta$ range of $10-80^{\circ}$ at wavelength 1.5406 as shown in fig.7. The associated data of diffractogram depict the $2 \theta$ value for each peak, relative intensity and interplanar spacing (d-values). By using Scherer's formula the average crystallite size (dxrd) of the metal complexes was calculated. The XRD patterns exhibited sharp crystalline peaks which specify the crystalline phase of metal complexes [25, 26]. The $\mathrm{Cu}(\mathrm{II}), \mathrm{Co}(\mathrm{II}), \mathrm{Ni}(\mathrm{II})$ and $\mathrm{Mn}(\mathrm{II})$ Schiff base metal complexes have an average crystallite size of $1,21,45$ and $41 \mathrm{~nm}$ respectively. The $\mathrm{h}^{2}+\mathrm{k}^{2}+\mathrm{l}^{2}$ values were $1,2,3,4,5,6,9,10$ and 11 . The calculated lattice parameter for metal complexes are $a=b=c=7.5,7.04,6.59 \& 3.18$. The observed values of the metal complexes may belong to hexagonal or tetragonal systems.

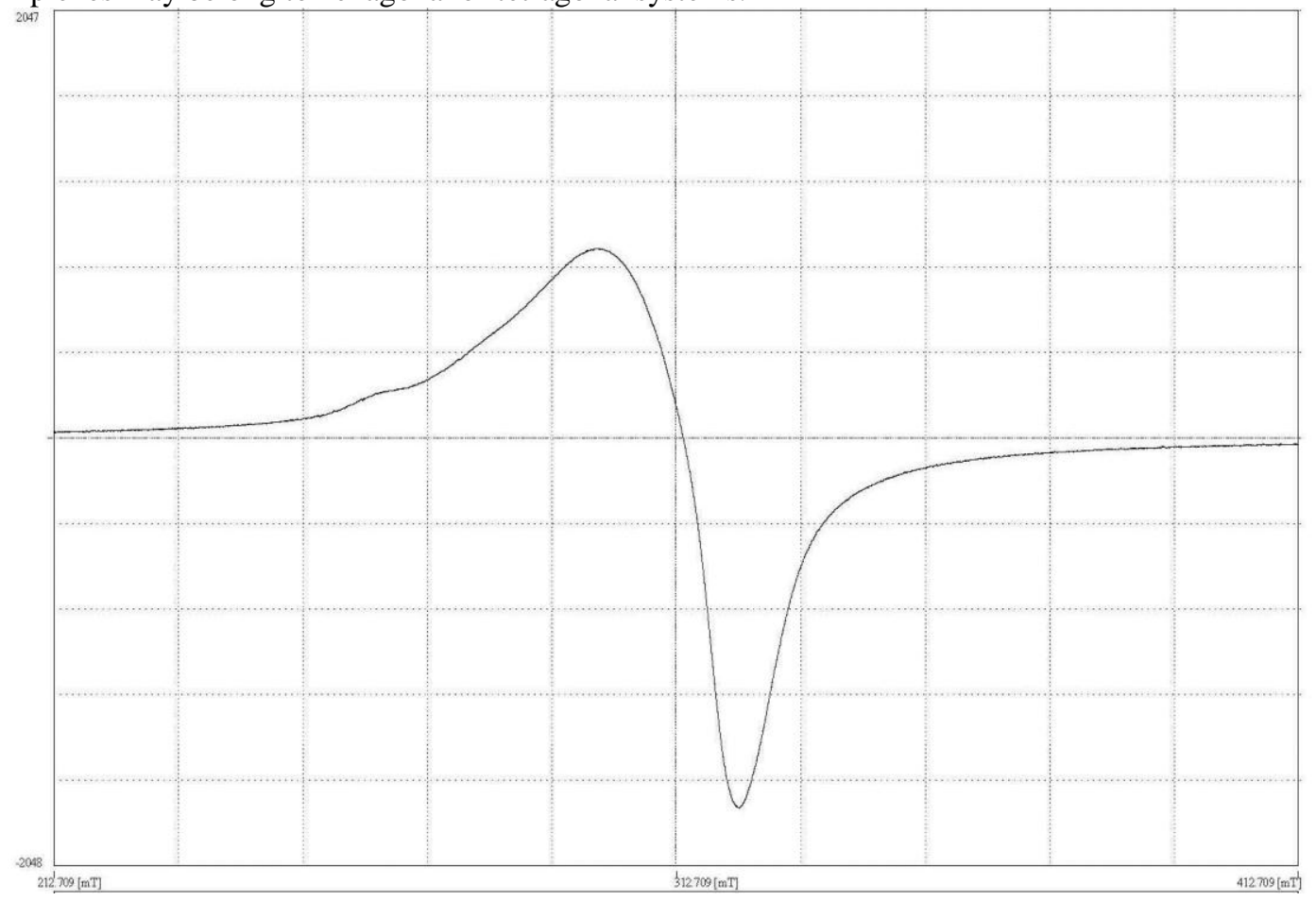

Fig. 4:- ESR spectrum of homo-binuclear $\mathrm{Cu}(\mathrm{II})$ complex 


\section{Cytotoxic bioassay:-}

In vitro cytotoxicity of synthesized compounds was inspected by means of the standard MTT colorimetric assay. It is one of the broadly used methods against breast cancer cell line (MCF7). The toxic results were compared with the activity of the known anticancer reference drug (doxorubicin). The screening results were shown in fig.6. Cytotoxicity of the tested compounds was evaluated at six concentrations $(250,100,50,25,12.5$ and $6.5 \mu \mathrm{g} / \mathrm{ml})$ by median growth inhibitory concentration $\left(\mathrm{IC}_{50}\right)$ which inhibits cell growth producing $50 \%$ cytotoxic effect against cancer cells after 48 hours. From the results we have concluded that the $\mathrm{Cu}$ (II) and $\mathrm{Co}$ (II) complexes has higher toxic activity than the other compounds. The $\mathrm{IC}_{50}$ values also display that all compounds documented moderate antitumor activity against MCF7 cell lines without causing significant damage to the normal cells [27, 28].

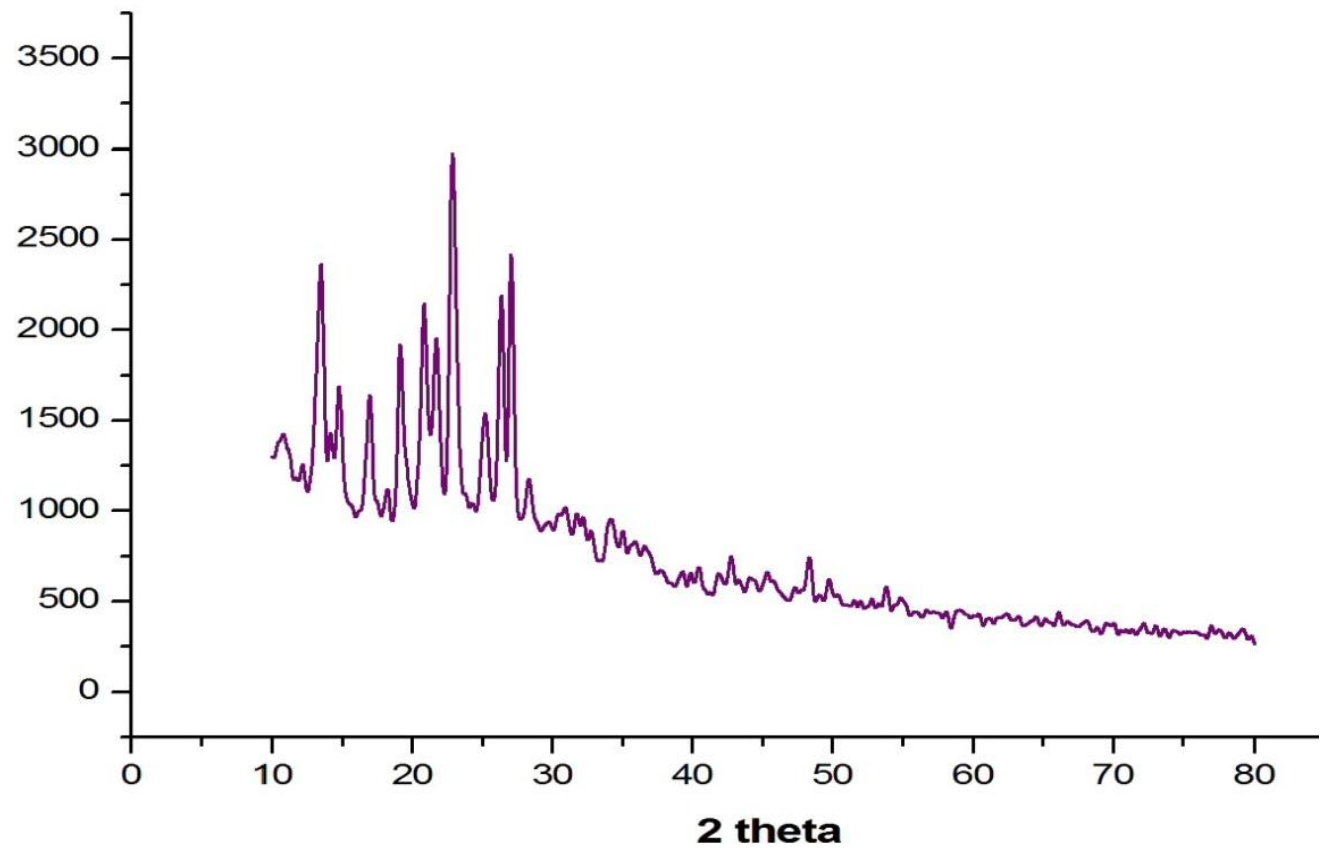

Fig. 5:- P-XRD for homo-binuclear Co(II) complex

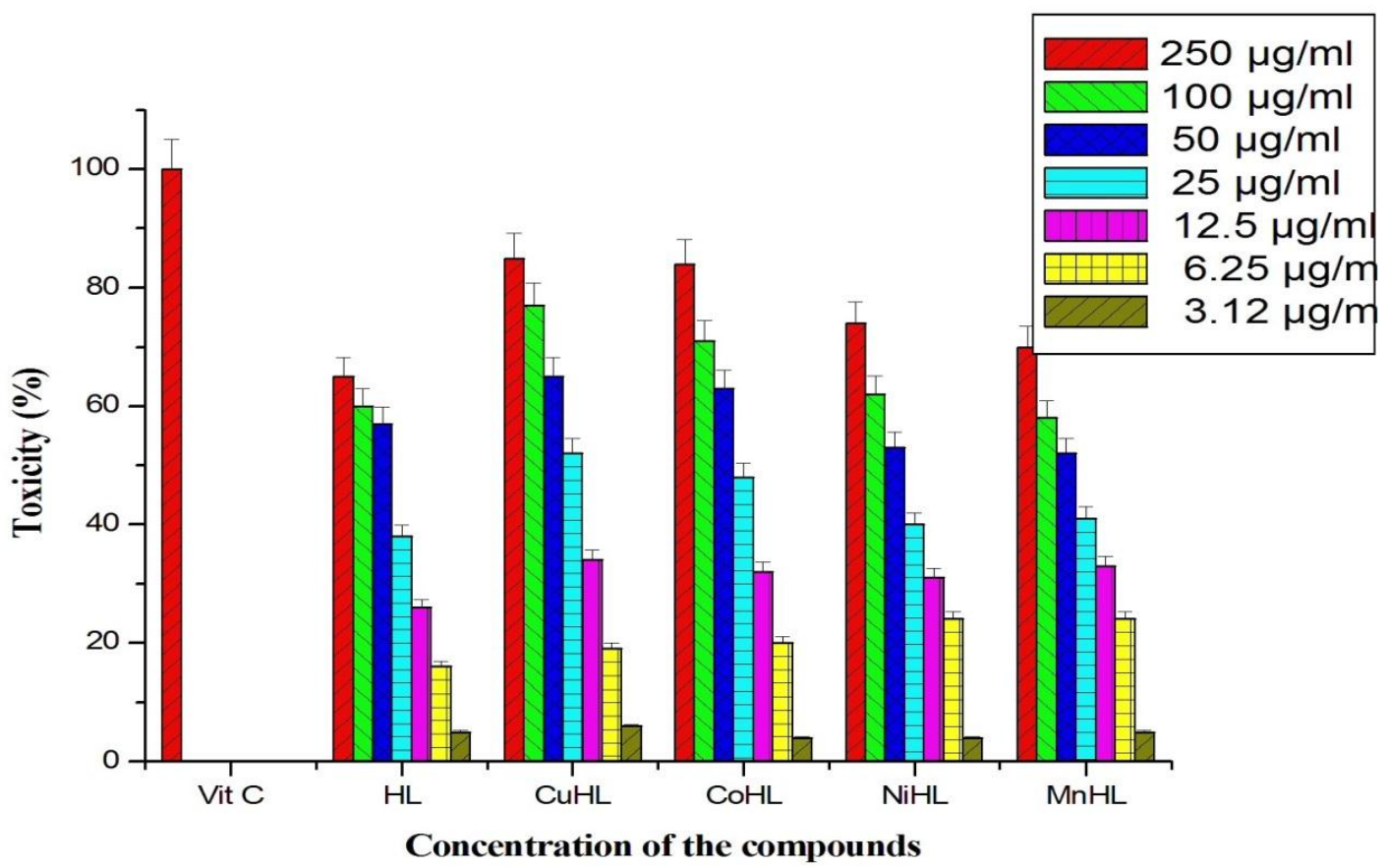

Fig. 6:- Anticancer activity of Schiff base and its homo-binuclear metal complexes 


\section{Antimicrobial bioassay:-}

Antibacterial and antifungal activities of Schiff ligand and their homo binuclear metal complexes were tested against two gram positive bacterias viz., S. aureus, B. Subtilis, two gram negative bacterias viz., E. coli, S.Typhi and two fungicides viz., Aspergillus flarusa, A.fumigatus. The microbial activity of the synthesized compounds was also compared with standard antibacterial agent (Ciprofloxacin) and antifungal agent (Ketoconazole). A comparative study of minimum inhibitory concentration (MIC) values showed that $\mathrm{Cu}(\mathrm{II})$ and $\mathrm{Co}(\mathrm{II})$ metal complexes exhibited auspicious results when compare with $\mathrm{Ni}(\mathrm{II}), \mathrm{Mn}(\mathrm{II})$ complexes and Schiff base ligand against the above cited microorganisms, and this was mainly occurring, the Schiff base coordinated to the metal ions (fig.7). There are several reports were also cited for $\mathrm{Co}$ (II) and $\mathrm{Cu}$ (II) complexes showing better bioactivities [29]. Moreover, the heterocyclic Schiff bases having the different functional group to interact with nucleoside bases with greater tendency even after complexation with metal ions. The enhancement microbial activity of the metal complexes may be occurring on the basis of Overtone's concept and Tweedy's Chelation theory [30, 31]. According to these theories, in a metal complex, the coordination reduces the polarity of metal ion because the partially sharing of positive charge of the metal with donor atoms of the ligand within the chelating ring system. This could be increases the lipophilic nature of the central metal chelate atom and favors its permeation through the lipid layer of the microbial membranes more effectively thus destroying them more violent.

A glance of activity order for bacterial species was found to be

Ciprofloxacin > CuHL > CoHL > NiHL > MnHL > HL

With fungicides the order of activity was found to be

Ketoconazole $>\mathrm{CoHL}>\mathrm{CuHL}>\mathrm{NiHL}>\mathrm{MnHL}>\mathrm{HL}$

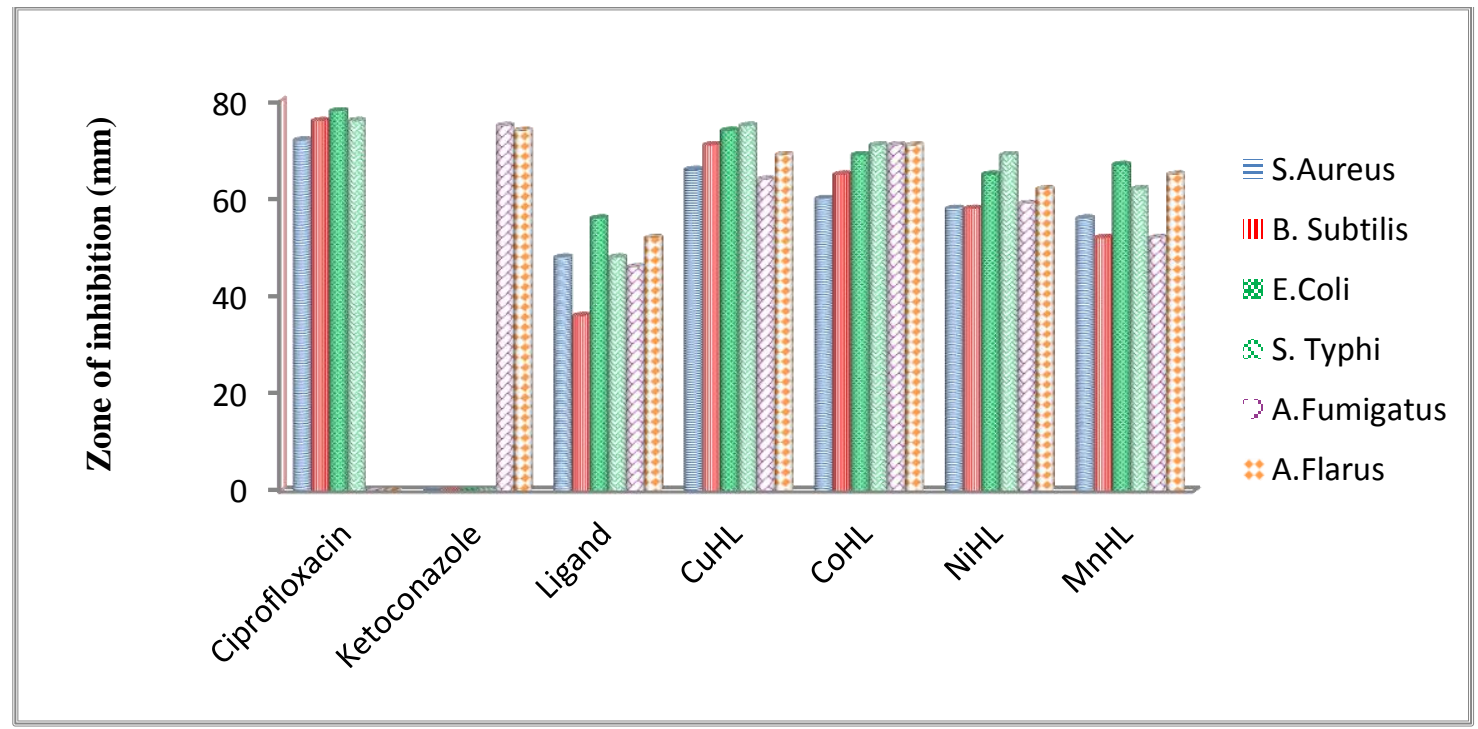

Fig. 7:- Antimicrobial activity of Schiff base ligand and their binuclear metal complexes

\section{Antioxidant bioassay:-}

The free radical DPPH (2,2'-diphenyl-1-picrylhydrazyl) inhibition assay showed that all synthesized compounds having moderate antioxidant property to different concentrations compare with standard ascorbic acid (Vit-C). Generally, several literatures report the metal complexes have more activity, where the ligand has antioxidant activity and it is predictable that the metal moiety will increase its activity [32]. Among the observed compounds $\mathrm{Cu}$ (II) complex demonstrated a good free radical scavenging activity, whereas others have shown that reasonable activity (fig.8). 


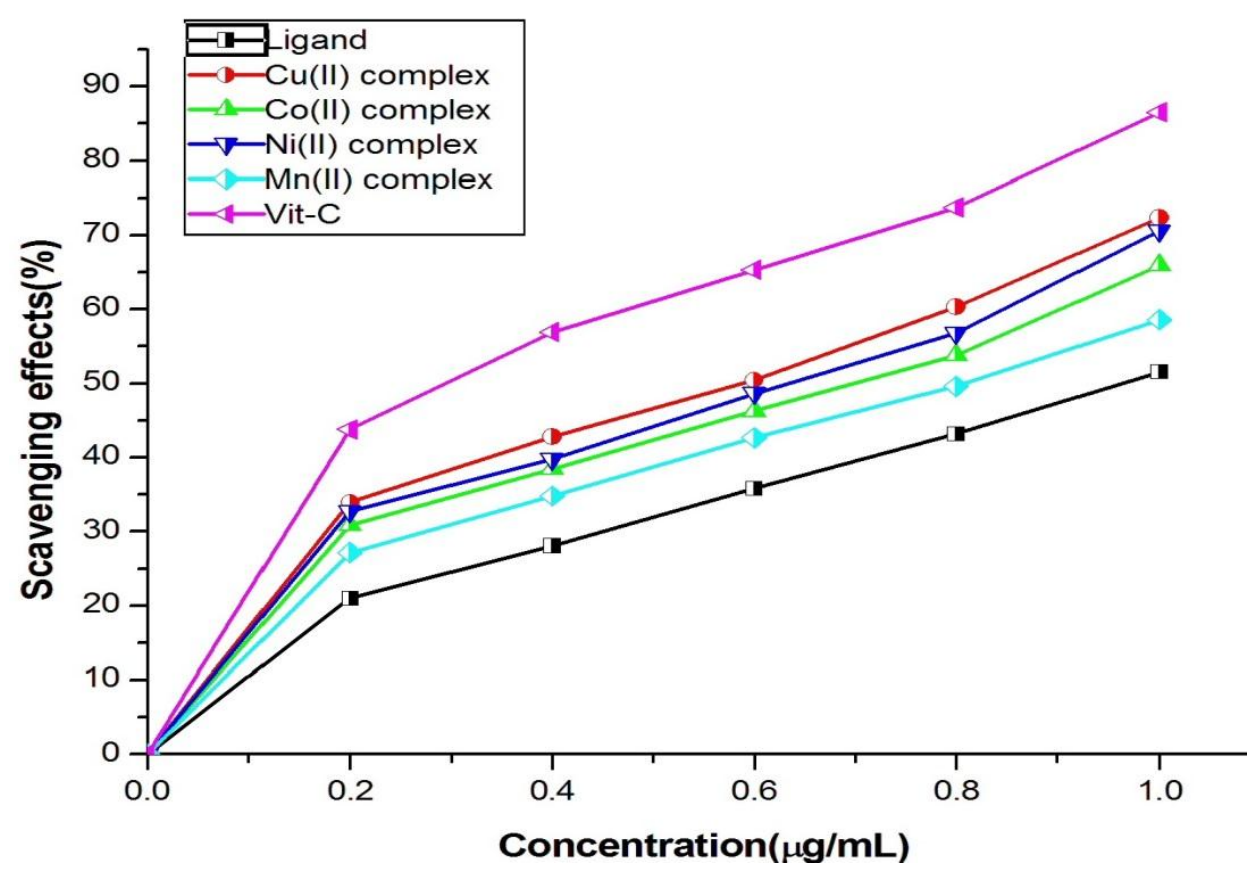

Fig. 8:- Antioxidant activity of Schiff base ligand and their binuclear metal complexes

\section{Conclusion:-}

The cautious review of this research work leads to the following conclusions:

2,6-diaminopyridine based Schiff base has successfully synthesized and its coordination behavior with metal ions (Cu(II), $\mathrm{Co}(\mathrm{II}), \mathrm{Ni}(\mathrm{II})$ and $\mathrm{Mn}(\mathrm{II})$ ) also studied. On the basis of spectral studies octahedral geometry was suggested for all the metal complexes. The molecular formulae of the synthesized compounds were confirmed by mass spectra. Thermal behavior studies suggested that the metal complexes were more stable. The microbial screening of the tested compounds which led to the assumption that metal complexes have higher activity than free Schiff base ligand. Furthermore, the cytotoxicity results concerned that $\mathrm{Cu}$ (II) and $\mathrm{Co}$ (II) complexes has been more effective against MCF7 cell line without affecting momentous destruction to the normal cells than its Schiff base ligand and other metal complexes (Ni(II) and $\mathrm{Co}(\mathrm{II})$ ).

\section{Acknowledgment:-}

The author thankfully acknowledges the Periyar University, Salem. for the sponsorship of this work under the University Research Fellowship (Ref: PU/A\&A-3/URF/2014).

\section{References:-}

1. Shakir M, Shahid N, Sami N, Azam M, Khan A. U, Synthesis, spectroscopic characterization and comparative DNA binding studies of Schiff base complexes derived from 1-leucine and glyoxal, Spectrochim. Acta Part A. 2011, 82, 31-36.

2. Razakantoanina V, Phung N.K.P, Jaureguiberry G, Antimalarial activity of new gossypol derivatives, Parasitol. Res. 2000, 86, 665-668.

3. Royer R.E, Deck L.M, Vander Jagt T.J, Synthesis and anti-HIV activity of 1,1'-dideoxygossypol and related compounds, J. Med. Chem. 1995, 38(13), 2427-2432.

4. Youssef S.N, El-Zahany E, El-Seidy A.M.A, Caselli A, Cenin S, Synthesis and characterization of some transition metal complexes with a novel Schiff base ligand and their use as catalysts for olefin cyclopropanation, J. Mol, Catal. A: Chem., 2009, 308, 159-168.

5. Patil A.S, Naika, H.V, Kulkarnia D.A, Badami S.P, DNA cleavage, antimicrobial, spectroscopic and fluorescence studies of $\mathrm{Co}(\mathrm{II}), \mathrm{Ni}(\mathrm{II})$ and $\mathrm{Cu}(\mathrm{II})$ complexes with $\mathrm{SNO}$ donor coumarin Schiff bases, Spectrochim. Acta Part A, 2010, 75, 347-354.

6. Indira Devi G, GeethA P, Veena V, Antifungal studies of Transition metal complexes of Schiff base Derived from Anthracene Carboxaldehyde-L-Histidine, Asian J. Chem 2004, 16, 493-500. 
7. Sheng X, Guo X, LuM.X, Lu Y.G, Shao Y, Liu F, Xu Q, DNA Binding, Cleavage, and Cytotoxic Activity of the Preorganized Dinuclear Zinc(II) Complex of Triazacyclononane Derivatives, Bioconjugate chem. 2008, 19(2), 490-498.

8. Koval I. A, Huisman M, Stassen A. F, Gamez P, Lutz M, SpekA. L, Pursche D, Krebs B, Reedijk J, New dinuclear $\mathrm{Co}(\mathrm{II})$ and $\mathrm{Mn}$ (II) complexes of the phenol-based compartmental ligand containing formyl and amine functions: structural, spectroscopic and magnetic properties, J. Inorg. Chim. Acta 2004, 357, 294-300.

9. Karthikeyan M.S, Parsad D.J, Poojary B, Bhat K.S, Holla B.S, Kumari N.S, Synthesis and biological activity of Schiff and Mannich bases bearing 2,4-dichloro-5-fluorophenyl moiety, Bioorg. Med. Chem. 2006, 14, 74827489 .

10. Mladenova R, Ignatova M, Manolova N, Petrova T, Rashkov I, Preparation, characterization and biological activity of Schiff base compounds derived from 8-hydroxyquinoline-2-carboxaldehyde and Jeffamines ED®, Eur. Polym. J. 2002, 38(5), 989-999.

11. Seth B. K, Ray A, Saha A, Saha P, Basu S, Potency of photoinduced electron transfer and antioxidant efficacy of pyrrole and pyridine based $\mathrm{Cu}$ (II)-Schiff complexes while binding with CT-DNA, J. Photochem. Photobiol. 2014, 132, 72-84.

12. Bindu P, KurupM.R.P, Satyakeerthy T.R, Epr, cyclic voltammetric and biological activities of copper(II) complexes of salicylaldehyde N(4)-substituted thiosemicarbazone and heterocyclic bases, Polyhedron 1998, 18, 321-331.

13. James S, Suresh Kumar D, Alexander V, Synthesis of lanthanide(III) complexes of 20-membered octaaza and hexaaza Schiff-base macrocycles, J. Chem. Soc., Dalton Trans., 1999, 1773-1777.

14. Jayalakshmi R, Rajavel R, Synthesis and Characterisation of some novel Schiff base metal complexes: Spectral, XRD, Photoluminescence and Antimicrobial Studies, Chem Sci Rev Lett., 2015, 4(15), 851-859.

15. Sibous L, Bentouhami E, Ahmed Khan M, Synthesis, Characterization, and Electrochemical Behaviour of Cobalt(II) and Nickel(II) Complexes with $\mathrm{N}_{2} \mathrm{O}_{2}$ Chelating Ligand 4,4'-(Biphenyl-4,4'-diyldinitrilo)dipentan-2one, J. Inorg. Chem., 2013, Article ID 104979, 1-11.

16. Ali M. A, Mirza A. H, Butcher R, J. Synthesis and characterization of copper(II) complexes of the methylpyruvate Schiff base of S-methyldithiocarbazate (Hmpsme) and the X-crystal structures of Hmpsme and [Cu(mpsme)Cl], Polyhedron, 2001, 20(9-10), 1037-1043.

17. Alias M, Kassum H, Shakir C, Synthesis, physical characterization and biological evaluation of Schiff base M(II) complexes, Journal of the Association of Arab Universities for Basic and Applied Sciences, 2014, 15, 28 34.

18. Kose D. A, Kaya A, Necefoglu H, Synthesis and Characterization of Bis(N,N-diethylnicotinamide) mHydroxybenzoate Complexes of $\mathrm{Co}(\mathrm{II}), \mathrm{Ni}(\mathrm{H}), \mathrm{Cu}(\mathrm{II})$, and $\mathrm{Zn}(\mathrm{II})$, Russian J. Coord. Chem. 2007, 33, 422-427.

19. Rathore K, RajivK.R, Singh H.B, Structural, Spectroscopic and Biological Aspects of O, N- Donor Schiff Base Ligand and its $\mathrm{Cr}(\mathrm{III}), \mathrm{Co}(\mathrm{II}), \mathrm{Ni}(\mathrm{II})$ and $\mathrm{Cu}(\mathrm{II})$ Complexes Synthesized through Green Chemical Approach, Eur. J. Chem. 2010, 7, S566-S572.

20. Zayed E. M, Mohamed G. G, Hindy A. M. M, Transition metal complexes of novel Schiff bases synthesis, spectroscopic characterization, and in vitro antimicrobial activity of complexes, J Therm Anal Calorim., 2015, 120, 893-903.

21. Chandra S, Kumar U, Spectral and magnetic studies on manganese(II), cobalt(II) and nickel(II) complexes with Schiff bases, Spectrochim. Acta Part A, 2005, 61, 219-224.

22. El-Medani S.M, Ali O.A.M, Ramadan R.M, Photochemical reactions of group 6 metal carbonyls with Nsalicylidene-2-hydroxyaniline and bis-(salicylaldehyde) phenylenediimine, J. Mol. Struct., 2005, 738, 171-177.

23. Chandra S, Gupta L. K, Electronic, EPR, magnetic and mass spectral studies of mono and homo-binuclear $\mathrm{Co}$ (II) and $\mathrm{Cu}(\mathrm{II})$ complexes with a novel macrocyclic ligand, Spectrochim. Acta Part (A), 2005, 62, 1102 1106.

24. Herrera A.M, Staples R.J, Kryotov S.V, Nazarenko A.Y, Vakimova E, Nickel(II) and copper(II) complexes with pyridine-containing macrocycles bearing an aminopropyl pendant arm: synthesis, characterization, and modifications of the pendant amino group, Dalton Trans. 2003, 846-856.

25. Hentry N.F.M, Lipson H, Wooster W.A, Interpretation of X-ray Diffraction Photographs; Macmillan, London, 1951.

26. Sindhu Y, Athira C. J, Sujamol M. S, Joseyphus R. S, Mohanan K, Synthesis, characterization, DNA cleavage, and antimicrobial studies of some transition metal complexes with a novel Schiff base derived from 2aminopyrimidine, Synth. React. Inorg. Met.-Org. Nano-Metal. Chem. 2013, 43, 226-236. 
27. Binh L.H, Thuy Van N.T, Kien V.T, MyN. T. T, ChinhL. V, Nga N. T, Tien H. X, Thao D. T, Vu T. K, Synthesis and in vitro cytotoxic evaluation of new triazole derivatives based on artemisinin via click chemistry, Med Chem Res., 2016, 25, 738-750.

28. Zhang J, Ma L, Lu H, Wang Y, Li S, Wang S, Zhou G, Synthesis, characterization and cytotoxicity of platinum(II)/palladium(II) complexes with 1,3-diaminopropane and 4-toluensulfonyl-L-amino acid dianion, Eur. J. Med. Chem. 2012, 58, 281-286.

29. Phaniband M. A, Dhumwad S. D, Pattan S. R, Synthesis, characterization, antimicrobial, and DNA cleavage studies of metal complexes of coumarin Schiff bases, Med Chem Res. 2011, 20, 493-502.

30. Sharma A. K, Chandra S, Complexation of nitrogen and sulphur donor Schiff's base ligand to $\mathrm{Cr}(\mathrm{III})$ and $\mathrm{Ni}(\mathrm{II})$ metal ions: Synthesis, spectroscopic and antipathogenic studies, Spectrochimica Acta A, 2011, 78, 337-342.

31. Ozer C.K, Arslan H, VanDerveer D, Kulcu N, Synthesis and Characterization of N-(Arylcarbamothioyl)cyclohexanecarboxamide Derivatives: The Crystal Structure of N-(Naphthalen-1ylcarbamothioyl)cyclohexanecarboxamide, Molecules, 2009, 14(2), 655-666.

32. Bukhari, S.B.; Memon, S.; Mahroof-Tahir, M.; Bhanger, M.I. Synthesis, characterization and antioxidant activity copper-quercetin complex, Spectrochim. Acta Mol. Biomol. Spectrosc., 2009, 71(5), 1901-1906. 